\title{
Serum hypercoagulability states in Coats' disease
}

\author{
Fariba Ghassemi' \\ Carol L Shields ${ }^{2}$ \\ Masoumeh Mohebbi' \\ Mehdi Nili Ahmadabadi' \\ Fatemeh Morsali' \\ Siamak Sabour ${ }^{3,4}$ \\ 'Ocular Oncology and Retina and \\ Vitreous Service, Farabi Eye Hospital, \\ Tehran University of Medical Sciences, \\ Tehran, Iran; ${ }^{2}$ Ocular Oncology \\ Service, Wills Eye Hospital, Thomas \\ Jefferson University, Philadelphia, \\ PA, USA; ${ }^{3}$ Safety Promotion and \\ Injury Prevention Research Centre, \\ ${ }^{4}$ Department of Clinical Epidemiology, \\ School of Health, Shahid Beheshti \\ University of Medical Sciences, \\ Tehran, Iran
}

This article was published in the following Dove Press journal:

Clinical Ophthalmology

8 February 2017

Number of times this article has been viewed

Purpose: The purpose of this study was to investigate the serum hypercoagulability state and common viral and protozoan infections in Coats' disease versus a normal control group.

Materials and methods: In this comparative case series, 22 consecutive patients with Coats' disease and 19 non-Coats' patients undergoing lensectomy for congenital, traumatic, or senile cataract between January 2011 and June 2014 were included. Laboratory data for hypercoagulability states and common viral and protozoan infections were investigated.

Results: The mean age for the Coats' group was 14.5 years (median 8 years, range: 2 months to 59 years), and for the control group it was 30.6 years (median 17 years, range: 2-82 years). In patients aged 10 years or younger, anticytomegalovirus immunoglobulin $\mathrm{G}(\operatorname{IgG})(P \leq 0.01)$, homocysteine $(P=0.03)$, and serum beta globulin $(P<0.001)$ were associated with Coats' disease. In those older than 10 years, higher serum protein $\mathrm{S}(P=0.04)$, beta globulin $(P=0.05)$, and gamma globulin $(P=0.04)$ were related to Coats' diagnosis. After adjusting for sex and age as confounding factors, only beta globulin was found to be associated with Coats' disease in logistic regression analysis (odds ratio: $1.8,95 \%$ confidence interval: $1.0-3.1, P=0.02$ ).

Conclusion: Serum beta globulin levels appear to be elevated in patients with Coats' disease. Keywords: anti-cytomegalovirus antibody, anti-herpes simplex antibody, Coats' disease, blood hypercoagulability state, retinal telangiectasia, serum electrophoresis

\section{Introduction}

Coats' disease first described in $1908,{ }^{1}$ is an idiopathic, typically unilateral, retinal vasculopathy that manifests with retinal telangiectasia, exudation, and retinal detachment. ${ }^{2-4}$ Coats' disease shows a male predominance, occurs more often in early childhood, and can lead to vision loss. Less commonly, this condition presents in teenagers and young adults often with less aggressive features. ${ }^{4}$ Coats' disease is a major simulator of retinoblastoma, a life-threatening pediatric ocular malignancy. ${ }^{1-4}$

In a study of angiographic findings of patients with Coats' disease, we noticed that occlusion of the retinal microvasculature with peripheral nonperfusion and shunt or microshunt formation between arterioles and venules in the retina was a prominent finding. ${ }^{5}$ This led to a speculation regarding serum factors that could lead to the microocclusions, such as a hypercoagulability state. Realizing that such a state would more likely lead to bilateral manifestations, we continued to explore serum features in Coats' disease. In 2012, we found a significantly high level of anti-cytomegalovirus (CMV) immunoglobulin $\mathrm{G}$ (IgG) in $92 \%$ of Coats' patients, higher serum proteins $\mathrm{C}$ and S, anti-herpes simplex virus (HSV) IgG I/II, alpha-2 globulin, and homocysteinemia in patients with Coats' disease $^{6}{ }^{6}$ In the second step of the analysis, it was planned to compare these factors in patients with Coats' disease with a control group. Herein, we evaluated serum hypercoagulable factors and viral and protozoan diseases in patients with Coats' disease versus normal controls.
Safety Promotions and Injury Prevention Research Centre, Shahid Beheshti University of Medical Sciences,

7th Floor, BIdg No 2 SBUMS, Arabi Ave, Daneshjoo Blvd, Velenjak, Tehran, Iran Tel/fax +98 2l 2242 I8I3

Email s.sabour@gmail.com (c) (1) (-) 2017 Ghassemi et al. This work is published and licensed by Dove Medical Press Limited. The full terms of this license are available at https://www.dovepress.com/terms.php hereby accept the Terms. Non-commercial uses of the work are permitted without any further permission from Dove Medical Press Limited, provided the work is properly attributed. For permission for commercial use of this work, please see paragraphs 4.2 and 5 of our Terms (https://www.dovepress.com/terms.php). 


\section{Materials and methods}

A prospective, single-center, comparative, consecutive crosssectional study was conducted for evaluating blood hypercoagulability state and infectious diseases, including CMV, herpes simplex, Epstein-Barr virus (EBV), toxoplasma and toxocara infections, in all patients with Coats' disease from February 2011 to December 2013. The research adhered to the tenets of the Declaration of Helsinki and the study was approved by Tehran University of Medical Sciences Institutional Review Board. Each patient or parents were carefully informed about the purpose of the research, and oral consent for laboratory examinations was obtained. Each patient or parents provided their written informed consent for this study.

Coats' disease was defined as unilateral or bilateral retinal vasculopathy characterized by retinal telangiectasia, capillary non-perfusion, multiple aneurysmal formation, exudation, and exudative retinal detachment. ${ }^{1-9}$ Patients with Coats' disease were grouped into those aged 10 years or less versus those older than 10 years. Clinical factors were compared to a control group, which consisted of patients with cataract undergoing lensectomy for congenital, traumatic, or senile cataract, with no evidence of retinal vascular disease.

Patients were evaluated with best-corrected visual acuity, indirect ophthalmoscopy for fundus features and color fundus photography, fluorescein angiography, and B-scan echography as needed. Fluorescein angiography was performed using a scanning laser ophthalmoscope (HRA, Heidelberg, Germany) or RetCam 120 (Clarity Medical Systems, Inc., Pleasanton, CA, USA).

The blood sample for serum studies was obtained from patients immediately before the treatment of Coats' disease. Treatment options included cryotherapy, photocoagulation, and intravitreal antivascular endothelial growth factor and/or subtenon triamcinolone depending on the patient's condition. Serum studies included hemoglobinopathies by hemoglobin electrophoresis; serum protein electrophoresis; coagulable states by serum protein $\mathrm{C}$, protein $\mathrm{S}$ level, antiphospholipid antibody, anticardiolipine antibody, antithrombin III, homocysteine level, and lipid profile; and infectious states by anti-HSV IgG, anti-CMV IgG, anti-EPV, anti-toxoplasma and anti-toxocara serum antibodies were measured with a enzyme-linked immunosorbent assay (ELISA) technique according to the manufacturer's protocol.

\section{Statistical analysis}

Statistical analyses were performed using Statistical Package for Social Sciences (v 17.0; SPSS, Chicago, IL, USA). All data are presented as mean \pm standard deviation (SD) or median (range of data). A Mann-Whitney test was used for quantitative or skewed distributed parameters. To assess the relationship between the qualitative variable and Coats' diagnosis, Fisher's exact test was applied. Logistic regression models were used to assess the relation of target exposure with Coats' diseases adjusting for possible confounding factors. A $P$-value of less than 0.05 was considered to be statistically significant.

\section{Results}

During the study period, there were 22 patients with Coats' disease (Figure 1) and 19 control patients. Of those with Coats' disease, 13 were 10 years or younger and 9 were older. (Table 1). The mean age for Coats' patients was 14.5 years (median 8 years, range: 2 month to 59 years), and for the control group it was 30 years (median 17 years, range: 2-82 years) (Table 2 ).

For those 22 patients with Coats' disease, the mean time from the first notice of the disease by patients (or parents) to diagnosis was $7.1 \pm 5.4$ months in the younger age group ( $\leq 10$ years old) and 7.8 \pm 9.9 months in the older age group $(>10$ years old). There were three $(13.6 \%)$ with bilateral involvement. Using the Coats' disease classification, ${ }^{4}$ the conditions of the eyes were classified as stage $1(n=0)$, stage $2(n=7)$, stage $3(n=12)$, stage $4(n=3)$, and stage $5(n=0)$. Total retinal detachment was seen in six $(28 \%)$ cases, whereas macular detachment was seen only in three (14\%) cases. In two $(9 \%)$ cases, there was no retinal detachment. The temporal and inferior regions were the most common sites for retinal detachment. Using fluorescein angiography, avascular non-perfused areas were found in $18(82 \%)$ cases, located in the periphery region in $10(46 \%)$ and in the macular region in $2(9 \%)$ (Table 1).

The first step of analysis was a comparison of the two age groups of Coats' disease ( $\leq 10$ years vs $>10$ years). This revealed no significant difference in the lipid profile, serum antithrombin III, anticardiolipine and antiphospholipid antibody serum antibody titer as well as polymerase chain reaction test for toxoplasma, toxocara, or EBV in the two groups. There was statistical difference (Mann-Whitney test-skewed deviation) in the two groups with regard to hemoglobin $(P=0.02)$, serum anti-HSV IgG $(P=0.05)$, anti-CMV IgG $(P=0.05)$, protein $\mathrm{C}(P=0.07)$, homocysteine $(P<0.01)$, serum alpha-2 globulin $(P<0.01)$, and serum gamma globulin $(P=0.05)$. Due to the small sample size in each age group, the logistic regression analysis was inconclusive.

The second step of analysis involved comparison of laboratory findings in Coats' disease versus the normal control group (Table 2). The serum levels in both Coats' and control 

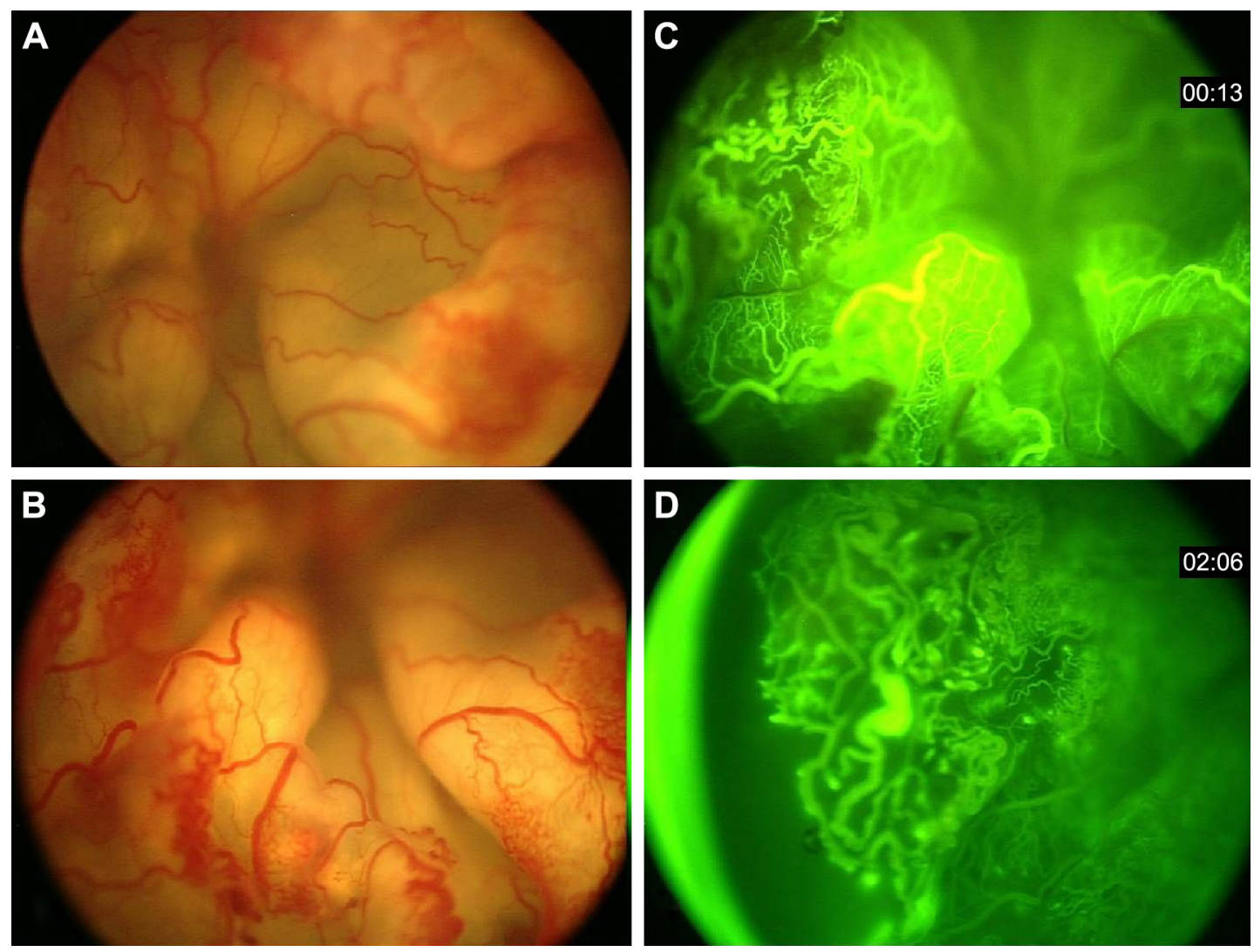

Figure I Clinical appearance of a patient with Coats' disease. (A and B) The fundus image of a patient with Coats' disease with exudative total retinal detachment. There is central arteriolar mild dilation and tortuosity. Peripheral telangiectatic vessels along aneurysmal changes are visible. Many microvascular shunts nearly in $360^{\circ}$ of periphery and midperiphery of retina are evident. (C and D) Angiographic finding as telangiectatic vessels, microaneurysms, sacular aneurysms, shunt vessels and peripheral avascular area in temporal and inferior retina.

patients were compared using the Mann-Whitney test. There was no significant difference in the lipid profile, serum antithrombin III, anticardiolipine, and antiphospholipid antibody serum antibody titer as well as polymerase chain reaction for toxoplasma, toxocara, or EBV. However, in the control group, the serum titer of anti-HSV IgG was higher and that of anti-CMV IgG was lower. In Coats' group, serum beta globulin was significantly higher in both young $(\leq 10$ years, $P<0.001)$ and old ( $>10$ years, $P=0.05)$ subgroups compared to controls. Applying Bonferroni correction did not change the results of serum beta globulin in the group less than 10 years old.

Logistic regression analysis for the main serologic findings in Coats' patients (irrespective of age) and control group was performed. After adjustment for age and sex, a significant association persisted for the presence of higher titer of serum beta globulin in Coats' disease compared to controls (odds ratio [OR]: 1.8, 95\% confidence interval [CI]: 1.0-3.1, $P=0.02$ ) (Table 3). Anti-HSV showed a mild negative impact ( $P=0.01$, OR $=-0.94)$ on the diagnosis of Coats' disease. After adjusting for age and sex, in those less than 10 years, the serum beta globulin was found to be significantly associated with the diagnosis of Coats' disease (OR: 6.3, 95\% CI: $1.2-32.6, P=0.02)$. In patients greater than 10 years with Coats' disease, there was a non-significant association with the diagnosis of Coats' disease (OR: 1.3, 95\% CI: 0.8-2.0, $P=0.24)$. For the older age, anti-HSV antibody was borderline significant (OR: 0.98, 95\% CI: 0.97-1.00, $P=0.05$ ). The small sample size precluded more conclusive results in the logistic regression analysis, adjusting for all other covariates.

\section{Discussion}

In this study, we could not find any association between hypercoagulability state and Coats' disease (compared to controls). The only factor associated with Coats' disease was elevated serum beta globulin mainly in the younger age group. We also recognized the negative impact of anti-HSV antibody on Coats' disease in the older age group.

Serum beta globulins are grossly measured by electrophoresis. Serum protein electrophoresis is a technique to assess the two major fractions of protein in blood, including albumin and globulins. ${ }^{10}$ Albumin is a transport protein that 
Table I Coats' disease based on the age category: demographic features

\begin{tabular}{|c|c|c|c|}
\hline Features & $\begin{array}{l}\text { Age } \leq 10 \text { years } \\
(13 \text { cases) } N(\%)\end{array}$ & $\begin{array}{l}\text { Age }>10 \text { years } \\
(9 \text { cases) } N(\%)\end{array}$ & $\begin{array}{l}\text { Fisher's exact test } \\
\text { P-value }\end{array}$ \\
\hline \multicolumn{4}{|l|}{ Sex } \\
\hline Male & $8(6 \mid .5)$ & $6(66.7)$ & \multirow{2}{*}{1.00} \\
\hline Female & $5(38.5)$ & $3(33.3)$ & \\
\hline \multicolumn{4}{|l|}{ Eye affected } \\
\hline Right & $8(6 \mid .5)$ & $5(55.6)$ & \multirow[t]{2}{*}{0.23} \\
\hline Left & $5(38.5)$ & $4(44.4)$ & \\
\hline \multicolumn{4}{|l|}{ Laterality } \\
\hline Unilateral & $10(76.9)$ & $9(100)$ & \multirow[t]{2}{*}{0.23} \\
\hline Bilateral & $3(23.1)$ & $0(0)$ & \\
\hline Telangiectatic vessels & $10(76.9)$ & $4(44.4)$ & 0.51 \\
\hline Aneurysms & $9(69.2)$ & $4(44.4)$ & 0.37 \\
\hline Exudation & $9(69.2)$ & $9(100)$ & 0.13 \\
\hline Subretinal fluid & $10(76.9)$ & $5(55.6)$ & 0.52 \\
\hline Tractional retinal detachment & $6(46.2)$ & $3(33.3)$ & 0.50 \\
\hline Subretinal fibrosis & $5(38.5)$ & I (II.I) & 1.00 \\
\hline Retinal traction & $2(15.4)$ & $2(22.2)$ & 0.70 \\
\hline Subretinal hemorrhage & $3(23.1)$ & I (II.I) & 1.00 \\
\hline Vitreous hemorrhage & $0(0)$ & $0(0)$ & 1.00 \\
\hline Pre-retinal hemorrhage & $3(23.1)$ & $0(0)$ & 0.53 \\
\hline Vasoproliferative tumor & $2(15.4)$ & $2(22.2)$ & 0.52 \\
\hline Retinal cyst & $5(38.5)$ & $2(22.2)$ & 1.00 \\
\hline Pigmentary changes & $6(46.2)$ & $2(22.2)$ & 0.48 \\
\hline Cystic changes in vitreous & $0(0)$ & I (II.I) & 0.09 \\
\hline Fibroglial tissue & $4(30.7)$ & I (II.I) & $0.4 \mathrm{I}$ \\
\hline Subretinal band & $3(23.1)$ & I (II.I) & 0.53 \\
\hline Retinal fold & $2(15.4)$ & I (II.I) & 0.10 \\
\hline Vascular sheeting & $8(61.5)$ & $2(22.2)$ & 0.25 \\
\hline \multicolumn{4}{|l|}{ (arterioles and/or venules) } \\
\hline Vascular occlusion & $3(23.1)$ & $0(0)$ & 0.49 \\
\hline \multicolumn{4}{|l|}{ (large arterioles and/or venules) } \\
\hline Peripheral non-perfusion & $6(46.2)$ & I (II.I) & 0.68 \\
\hline \multicolumn{4}{|l|}{ (more temporal) } \\
\hline Shunt vessels & I (7.6) & $0(0)$ & 0.68 \\
\hline Retinal tear & $2(15.4)$ & $0(0)$ & 0.50 \\
\hline
\end{tabular}

Table 2 Coats' disease based on the age category: comparison of serum values with normal controls

\begin{tabular}{|c|c|c|c|c|c|c|}
\hline \multirow[t]{2}{*}{ Features } & \multicolumn{3}{|c|}{ Age $\leq 10$ years median (range) } & \multicolumn{3}{|c|}{ Age $>10$ years median (range) } \\
\hline & $\begin{array}{l}\text { Coats' disease } \\
\text { group } \\
\text { (13 cases) }\end{array}$ & $\begin{array}{l}\text { Control } \\
\text { group } \\
(9 \text { cases) }\end{array}$ & $\begin{array}{l}\text { Mann-Whitney } \\
\text { (P-value) }\end{array}$ & $\begin{array}{l}\text { Coats' disease } \\
\text { group } \\
(9 \text { cases })\end{array}$ & $\begin{array}{l}\text { Control } \\
\text { group } \\
\text { (10 cases) }\end{array}$ & $\begin{array}{l}\text { Mann-Whitney } \\
\text { (P-value) }\end{array}$ \\
\hline Age (Mo) & $48(2-120)$ & $48(36-108)$ & 0.48 & $276(144-708)$ & 708 (204-984) & 0.07 \\
\hline WBC $\left(\times 10^{3} / \mathrm{dL}\right)$ & $8.8(5-6 I)$ & $6.8(5-101)$ & 0.10 & $7.5(5.5-9.5)$ & $8.6(5-11.3)$ & 0.35 \\
\hline $\mathrm{Hb}(\mathrm{g} / \mathrm{dL})$ & $13.3(9.4-15)$ & $12(11-14)$ & 0.36 & $15.3(13.4-16.6)$ & $15.4(\mid 3.4-16.9)$ & 0.90 \\
\hline PLT (I03/dL) & $372.5(260-627)$ & $354(222-490)$ & 0.61 & $28 I(2 I I-463)$ & $242(20|-3| 2)$ & 0.31 \\
\hline Serum anti-HSV $\lg G<20(\mathrm{U} / \mathrm{mL})$ & $0.2(0.1-52.8)$ & $7.0(3.4-160)$ & 0.004 & $3.8(0.1-20 \mathrm{I})$ & $201(3-201)$ & 0.02 \\
\hline Serum anti-CMV $\lg G<I(U / m L)$ & I $97.0(0.8-50 \mid)$ & $69.6(4.9-127)$ & $<0.01$ & $454(|24.8-50|)$ & $298(76.3-50 I)$ & 0.37 \\
\hline Protein C (70-130 unit\%) & $86(54-99)$ & $84(50-105)$ & 0.80 & $104(52-138)$ & $105.5(95-131.5)$ & 0.87 \\
\hline $\begin{array}{l}\text { Protein S } \\
\text { (male: } 77-143 \text {, } \\
\text { female: } 55-125 \text { unit\%) }\end{array}$ & $82(60-115)$ & $63(30-11)$ & 0.11 & $86(76-114)$ & $76.5(56-98)$ & 0.04 \\
\hline Homocysteine & $7(5.2-10)$ & $5(5-7.4)$ & 0.03 & $11.8(8.1-19.8)$ & $19.6(9.6-53)$ & 0.30 \\
\hline Serum albumin (g/dL) & $41.5(35.9-49.4)$ & 46.I (29.1-49.8) & 0.05 & $41.4(33-46.8)$ & $42.7(35.5-46.8)$ & 0.36 \\
\hline Serum $\alpha$ I globulin $(2-6 \mathrm{~g} / \mathrm{dL})$ & $4(2.1-6)$ & $3.3(2.9-3.9)$ & 0.05 & $4.3(3.2-6)$ & $4(2.2-5.1)$ & 0.23 \\
\hline Serum $\alpha 2$ globulin $(8-13 \mathrm{~g} / \mathrm{dL})$ & $16.6(11.4-20.5)$ & $16.3(14.9-20.9)$ & 0.88 & $12.6(\mid 1.8-16.2)$ & $15.5(12-18.7)$ & 0.006 \\
\hline Serum $\beta$ globulin ( $12-19 \mathrm{~g} / \mathrm{dL})$ & $18.7(|5.7-2| .8)$ & $15.2(13.5-17.1)$ & $<0.001$ & $18.2(\mid 6.1-21.9)$ & $16.2(14.8-22.2)$ & 0.05 \\
\hline Serum $\gamma$ globulin ( $15-25 \mathrm{~g} / \mathrm{dL})$ & $20.8(9.1-29.6)$ & $20.7(15.5-22.6)$ & 0.52 & $22.8(20.7-28)$ & $20(18-28.1)$ & 0.04 \\
\hline
\end{tabular}

Abbreviations: CMV, cytomegalovirus; Hb, hemoglobin; HSV, herpes simplex virus; IgG, immunoglobulin G; Mo, month; PLT, platelet; WBC, white blood cell count. 
Table 3 Coats' disease comparison with controls: adjusted to age and sex as confounding factors (logistic regression)

\begin{tabular}{lll}
\hline Variables & $P$-value & OR $(95 \% \mathbf{C I})$ \\
\hline Age & 0.82 & $0.99(0.9-1.0)$ \\
Sex & 0.16 & $0.12(0.00-2.3)$ \\
Serum anti-HSV IgG & 0.01 & $0.94(0.95-0.99)$ \\
Serum anti-CMV IgG & 0.07 & $1.01(0.99-1.00)$ \\
Serum beta globulin & 0.02 & $1.80(1.0-3.1)$ \\
\hline
\end{tabular}

Abbreviations: $\mathrm{Cl}$, confidence interval; HSV, herpes simplex virus; CMV cytomegalovirus; IgG, immunoglobulin G; OR, odds ratio.

plays a significant role in fat solubility. ${ }^{11}$ The globulin fraction of blood includes hundreds of serum proteins, including carrier proteins, enzymes, complement, and immunoglobulins. Globulins are divided into four groups by electrophoresis: alpha, alpha-2, beta, and gamma, depending on their migratory pattern between the anode and the cathode of the electrophoresis test. ${ }^{11}$ The beta fraction of serum globulins is known to have two peaks, named as beta 1 and beta 2 . Beta 1 is composed of mostly transferrin, and beta 2 contains beta-lipoprotein. ${ }^{12} \operatorname{IgA}$, IgM, and sometimes IgG, along with complement proteins (C3), beta-2 microglobulin, plasminogen, angiostatins, properdin, sex hormone-binding globulin, transferrin, hemopexin, and factor $\mathrm{H}$, can also be identified in the beta fraction. ${ }^{10-12}$ These proteins carry out numerous biological functions in the human body, including iron transport and monitoring immune response..$^{10,11}$

Beta globulin protein can be elevated or depressed in various diseases. Beta globulin is found to be elevated in iron deficiency anemia, hypercholesterolemia, pregnancy, estrogen therapy, and also substantially increased in liver disease. ${ }^{9,10,13,14}$ It is found to be decreased in malnutrition, cirrhosis, and immune deficiency due to decreased synthesis, and in nephrotic syndrome due to protein loss in the kidney. ${ }^{11}$

In this series of Coats' disease, the beta globulin fraction was elevated, which is particularly evident in patients lesser than 10 years. This age-related difference could correlate with milder manifestations of Coats' disease in older patients. The relationship of this fraction with Coats' disease is unclear, but could correlate to higher C3 (complement protein 3) level or other factors. Complement 3 is an important protein in the immune system, which plays a vital role in the acute phase response. It controls several biological processes, including cell lysis, chemotaxis, anaphylaxis, vascular permeability, and cellular membrane adhesion. This protein is categorized as a beta globulin and might represent the elevation of beta globulin in Coats' disease in this report. ${ }^{12,15-18}$

Chronic low-grade inflammation has been correlated with elevated C-reactive protein, as well as complement C3 plasma levels, and these can be predictive of arterial thrombotic events. ${ }^{16-20}$ Elevated C3 is also associated with prolonged fibrinolysis. ${ }^{18,21-23}$ Both of these roles could relate to the vascular pathology of Coats' disease.

The discrepancy found in the younger and older age groups could suggest a difference in the main pathophysiological basis of Coats' disease in children and adults. More studies are needed for the confirmation of this observation. There are limitations of this study, including the small sample size and unclear relevance of beta-globulin relationship to the condition studied. This relationship could be further explored with larger cohort and more precise fractionation of the beta-globulin subgroup to better understand the exact protein(s) that contribute to this finding and its relationship to Coats' disease.

\section{Conclusion}

This analysis demonstrated that children with Coats' disease showed elevated serum levels of beta globulin. We speculate that this finding could reflect the known fluorescein angiographic-evident ischemic component and possibly now a low-grade inflammatory component.

\section{Disclosure}

The authors report no conflicts of interest in this work.

\section{References}

1. Coats' G. Forms of retinal diseases with massive exudation. Royal London Ophthalmic Hosp Rep. 1908;17:440-525.

2. Smithen LM, Brown GC, Brucker AJ, Yannuzzi LA, Klais CM, Spaide RF. Coats' disease diagnosed in adulthood. Ophthalmology. 2005;112(6): 1072-1078.

3. Cahill M, O'Keefe M, Acheson R, Mulvihill A, Wallace D, Mooney D. Classification of the spectrum of Coats' disease as subtypes of idiopathic retinal telangiectasis with exudation. Acta Ophthalmol Scand. 2001;79(6): 596-602.

4. Shields JA, Shields CL, Honavar SG, Demirci H, Cater J. Classification and management of Coats disease: the 2000 Proctor Lecture. $\mathrm{Am}$ J Ophthalmol. 2001;131(5):572-583.

5. Ghassemi F, Shields CL, Mashayekhi A. Fluorescein angiographic findings in Coats' disease. In: Oral presentation in World Ophthalmology Congress 2012; February 16-20, 2012; Abu Dhabi, United Arab Emirates.

6. Ghassemi F, Sabour S. Coats disease and cytomegalovirus infection. Iran J Ophthalmol. 2012;24(2):75-78. Available from: http://irjo. org/browse.php?a_id=669\&slc_lang=en\&sid=1\&ftxt=1. Accessed December 20, 2016.

7. Jones JH, Kroll AJ, Lou PL, Ryan EA. Coats' disease. Int Ophthalmol Clin. 2001;41(4):189-198.

8. Egbert PR, Chan CC, Winter FC. Flat preparations of the retinal vessels in Coats' disease. J Pediatr Ophthalmol. 1976;13(6):336-339.

9. Chang MM, McLean IW, Merritt JC. Coats' disease: a study of 62 histologically confirmed cases. J Pediatr Ophthalmol Strabismus. 1984; 21(5):163-168.

10. McPherson, Pincus RA, Henry MR, Bernard J. Henry's Clinical Diagnosis and Management by Laboratory Methods. 22nd ed. Philadelphia, PA: Elsevier Saunders; 2011:231-244.

11. Busher JT. Serum albumin and globulin. In: Walker HK, Hall WD, Hurst JW, editors. Clinical Methods: The History, Physical, and Laboratory Examinations. 3rd ed. Boston, MA: Butterworths; 1990:497-499. 
12. O'Connell TX, Horita TJ, Kasravi B. Understanding and interpreting serum protein electrophoresis. Am Fam Physician. 2005;71(1): 105-112.

13. Gray SJ, Barron ES. The electrophoretic analyses of the serum proteins in diseases of the liver. J Clin Invest. 1943;22(2):191-200.

14. Ravel R. Clinical Laboratory Medicine: Clinical Application of Laboratory Data. 6th ed. St. Louis: Mosby; 1995:343-350.

15. Kilicarslan A, Uysal A, Roach EC. Acute phase reactants. Acta Medica. 2013;2(12):2-7. Available from: http://www.tip.hacettepe.edu.tr/ actamedica/2013/Acta13(2).pdf. Accessed December 20, 2016.

16. Ajjan R, Grant PJ, Futers TS, et al. Complement C3 and C-reactive protein levels in patients with stable coronary artery disease. Thromb Haemost. 2005;94(5):1048-1053.

17. Cojocaru IM, Cojocaru M, Muşuroi C, Muşuroi C, Druţă A, Băcanu M. Study of some markers of inflammation in atherothrombotic pathogenesis of acute ischemic stroke. Rom J Intern Med. 2002;40(1-4):103-116.

18. Ridker PM, Silvertown JD. Inflammation, C-reactive protein, and atherothrombosis. J Periodontol. 2008;79(8 Suppl):1544-1551.
19. D'Ambrosio AL, Pinsky DJ, Connolly ES. The role of the complement cascade in ischemia/reperfusion injury: implications for neuroprotection. Mol Med. 2001;7(6):367-382.

20. Munshi NC, Longo DL, Anderson KC. Plasma Cell Disorders: Harrison's Principles of Internal Medicine. Vol.1. 18th ed. New York, NY: The McGraw-Hill Companies; 2012:936-944. Available from: http://accessmedicine.mhmedical.com/content.aspx?bookid=331\& sectionid=40726850. Accessed December 20, 2016.

21. Howes JM, Richardson VR, Smith KA, et al. Complement C3 is a novel plasma clot component with anti-fibrinolytic properties. Diab Vasc Dis Res. 2012;9(3):216-225.

22. Schroeder V, Carter AM, Dunne J, Mansfield MW, Grant PJ. Proinflammatory and hypofibrinolytic phenotype in healthy first-degree relatives of patients with type 2 diabetes. J Thromb Haemost. 2010;8(9): 2080-2082.

23. Seya T, Nagasawa S, Matsukura M, Hasegawa H, Atkinson JP. Generation of $\mathrm{C} 3 \mathrm{~d}, \mathrm{~g}$ and $\mathrm{C} 3 \mathrm{~d}$ by urokinase-treated plasma in association with fibrinolysis. Complement. 1985;2(2-3):165-174.
Clinical Ophthalmology

\section{Publish your work in this journal}

Clinical Ophthalmology is an international, peer-reviewed journal covering all subspecialties within ophthalmology. Key topics include: Optometry; Visual science; Pharmacology and drug therapy in eye diseases; Basic Sciences; Primary and Secondary eye care; Patient Safety and Quality of Care Improvements. This journal is indexed on

\section{Dovepress}

PubMed Central and CAS, and is the official journal of The Society of Clinical Ophthalmology (SCO). The manuscript management system is completely online and includes a very quick and fair peer-review system, which is all easy to use. Visit http://www.dovepress.com/ testimonials.php to read real quotes from published authors. 